\title{
Southern Leyteño's folklore narratives on lifestyle and leisure
}

Borong, Norlyn L. $\triangle$

Southern Leyte State University, Philippines (norlynborong44@gmail.com)

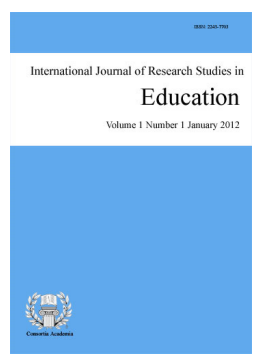

Accepted: 29 July 2021

ISSN: 2243-7703 Online ISSN: 2243-7711

OPEN ACCESS

\section{Abstract}

From the gathered folklore of Southern Leyte, this study aims to provide an opportunity to explore and gain knowledge about the lifestyle and leisure of Southern Leyteňos. The research design used in the study is a descriptive exploratory design. It is employed a purposive sampling strategy to collect folklore, in which they toured all of Southern Leyte's municipalities and asked for stories in various barangays. The researchers chose barangays from upland, lowland, and coastal areas in each municipality. A total of 65 narratives have been collected from the 19 municipalities. Findings revealed that Southern Leyteňos lifestyle and leisure includes hunting, pagtutuba, fishing, and farming. Southern Leyteňos spend their spare time sharing stories, balak, dancing, singing, and drinking tuba. Because they were used to playing, young people found riddles to be rather useful. Planting, fishing, and entrepreneurship are all superstitious notions. The bolhon or ajunay (bayanihan system) is regarded as a valuable cultural practice in which it serves as a tool for avoiding difficulties in jobs. The findings of this study should be used and incorporated into teaching children about the culture of the people who live in the neighborhood where their school is located.

Keywords: ajunay, balak, bayanihan system, bolhon, pagtutuba, superstitious 


\section{Southern Leyteño's folklore narratives on lifestyle and leisure}

\section{Introduction}

Southern Leyteños is known for being hardworking and a family-oriented people at the same time recognizes the value of socialization. Thus, it is a customary practice that after toiling their lands, attending to their farms and fishing, they gather to eat and enjoy drinking locally produced wine commonly known as tuba. During the gathering, people share their life experiences, exchange folktale stories and tell jokes. However, with the advent of modern technologies in Southern Leyte, it can be noticed that it affected how people value the commonly practiced socialization, particularly the youth. It is observed that a lot of the younger generation are hook on their smartphones and televisions, spending almost entirely their time attending to activities brought by modern technological artifacts. Because of that, many of the younger generations are not fully aware of how people in the past live and spend their time as a member of the family and as part of the community. Thus, the younger generation of Southern Leyte's changing behavior towards socialization is alarming, which necessitates educating the younger generations.

According to Abad et al. (2019), studying local culture increases cultural awareness, particularly to people who are part of that community. Culture serves as an interface of the past and present that influences how people move forward into the future. It serves as an identity for every society, where their way of life results from their history, stories, experiences, knowledge, beliefs and traditions. It is deemed imperative to highlight cultural beliefs and practices coming from various provinces and regions of the Philippines to take pride and honor in their heritage. Exploring and examining specific cultures is one way of preserving literature but, at the same time, their ethnicities. Therefore, this study deemed that it is essential to investigate and present the tradition of lifestyle and leisure among Southern Leyteňos using folk narratives. The study considered how people in the past live and value among the younger generation of Southern Leyte. For literature expresses man's innermost and unperceived thoughts, feelings, sentiments, ideas and aspirations.

Moreover, folk literature undoubtedly is essential, and it is where people can source values, traditions and customs. Filipino literature is colorful and interesting, and our folk literature paints intimate pictures of Filipino life and character that are unrecorded in historical documents and archaeological relics. The study, in addition, claims that folktales need to be preserved because they play an essential role in cultural identity and development. As Nhung (2016) emphasized, folktales provide an excellent source of cultural information; through folk stories, children learn about the value of family, respect towards other people, and love.

In addition, it is observed that some educators fail to see and incorporate in their lessons the value of having students the knowledge about their traditions and culture, probably due to lack of knowledge. Stavrou (2015) pointed out that educators are responsible for introducing local literature. As the teacher imparts folklore, it would help students enhance their interest in local culture, accept the uniqueness of one's identity, and cultivate respect for other cultures. Thus, this study deemed that it would provide educators of Southern Leyte the necessary knowledge and understanding of the lifestyle and leisure among the Southern Leyteňos in the past that can be useful in educating students the value and expertise of Southern Leyte's culture and tradition.

Rahim et al. (2018) also claimed that many moral values in the literature could mold the identity and personality of children. It means that the values and culture embedded in the folklore have played a significant role in helping the young generation become aware of the meaning of each value in their everyday lives because literature like folklore is the reflection of every individual's life. It is unfeasible to and a work of literature that excludes the morale and values of the society because the researchers believed every writer is part and parcel of the society where they belong. Recently, interest in folklore seems to have diminished due to various factors that particularly lessen local legend interest. Appell (2010) believed that folklore mirrors the nature of life and human 
responses to challenges. It accounts for society's belief systems, history, and values, providing authentic guidance and direction on how to live one's life. However, with the rapid expansion and the arrival of literacy, the core of this literature and its art eventually disappear.

As a whole, this study is made possible because it deemed that analyzing the collected folklore of Southern Leyteňos provides an opportunity to understand and gain knowledge about the lifestyle and leisure among Southern Leyteños. Thus, this study is significant to future scholars and the academe where it would serve as a future reference in the study of Southern Leyte and at the same time beneficial, especially to the younger and future generations of Southern Leyte.

\section{Theoretical Conceptual Framework}

The people of Southern Leyte hold a vast array of folk tales such as legends, myths and jokes; however, these folk tales are gradually and alarmingly no longer gaining enthusiasm, particularly with the younger generation. The result of the analysis of the lifestyles and leisure of Southern Leyteňos is anchored on the statement that folklore, mirrors culture, frequently reveals the areas of particular concern (Dundes, 2007). It serves as a mirror of culture, and it is a mirror well worth looking within. For example, if a teacher encourages their class to examine their folklore or, better yet, sends them out with collecting projects, such as managing the folklore of a group from another "culture, " it can give students an educational experience immeasurable value. This means that we need to use every available means to help better understand ourselves and our society. For this reason, analyzing collected folklore would provide a comprehensive perspective of Southern Leyteňos' lifestyle and leisure in the past.

Furthermore, Rahim et al. (2018) pointed out that the values and culture embedded in the folklore have played a significant role. Helping the young generation become aware of the meaning of each value in their everyday. Literature mirrors the lives of the people who own the story. Stories or events conveyed in oral literature are sourced from events in society with the narrator's imagination. It is emphasized in the $\mathrm{K}$ to 12 curricula; it is imperative to localize and contextualize local literature.

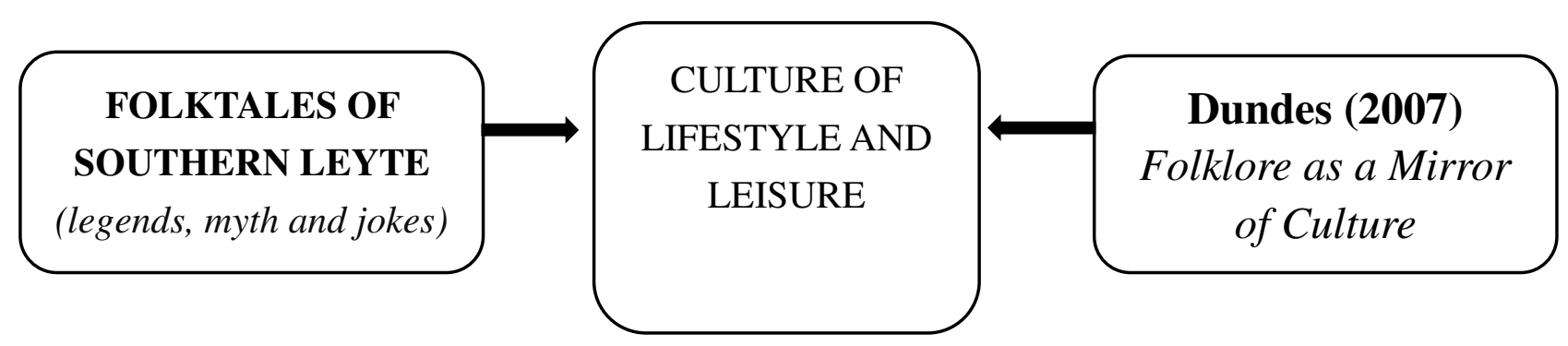

Figure 1. Theoretical framework

\section{Methodology}

The descriptive exploratory design is used in this study. The gathering of folklore is very vital to this research. The researchers employed a purposive sampling strategy to collect folklore, in which they toured all of Southern Leyte's municipalities and asked for stories in various barangays. The researchers chose barangays from upland, lowland, and coastal areas in each municipality. The first step was to get authorization from the province administration and then from the barangay level.

The gathered folklore was used to examine Southern Leyte's culture, with a focus on lifestyle and leisure. A total of 65 narratives have been collected from the 19 municipalities. This collection is diverse and has a variety of themes. To ensure the validity of the narratives, they were cross-checked with other informants and barangay 
officials. The fieldwork took place during a four-month period. The stories were sorted and coded into topics. It was then grouped and thematized to produce more precise themes that depicted the many lifestyles and leisure activities available in Southern Leyte.

\section{Result and Discussion}

In this part explain the result seen in the people of Southern Leyte's lifestyle and leisure in this section.

\subsection{Lifestyle Embodied in Folktales}

A person's, group's, or culture's usual way of life is referred to as a lifestyle (In Merriam-Webster). After compiling 64 narratives from various communities in Southern Leyte, it was determined that hunting, planting, fishing, and farming were the most popular ways of living.

Hunting is defined as the capture of any animal. People used to do this for food and entertainment in ancient times (Weisberger, 2017). Hunting was one of the leading lifestyles of the people in ancient times particularly in Southern Leyte. This is proved in the statement in Legend of Kanangkaa or story 61, paragraph 1 (S61, P1), Ang unang nagtawag ani kadtung mamusilay ug mga mananap. Naay mangutana nijang kauban na "naka triangle ka"? Buut pasabot nakaigu ka (The first to call it were hunters. His colleague asked "naka triangle ka?" It means you hit the animal?). From the story of Ang Kabit (Story1, Paragraph3-S1, P3) ... ijang giingnan ijang asawa nga muundang ko kung makuha na nahu ning mananapa (he told his wife, I will stop when I get this animal). Kay makuha nimu ni, mahimu kang milyunaryo kay mahal kaaju ning mananapa. (Because if you get it, you can be a millionaire because this animal is so expensive). These statements are just a few of the examples that hunting is one of the lifestyles of the people in Southern Leyte.

One of the lifestyles witnessed in Southern Leyte is making wine from coconut (pagtutuba). The island of Leyte is home to the Philippines' largest coconut plantation (Guerero, 2019). Tuba (coconut wine) is made from the pulp of coconuts. It was one of the main lifestyles of Southern Leyte people back then. This is proved in the Legend of Ang Mananggiti ug ang Amerikana (Story 59, Paragraph2- S2, P2) .....kay ang ilang sanggutan usa ka gatus ka puno.... (They have 100 coconut trees that are sources of tuba).

Fishing was also a major source of income for the residents of Southern Leyte at the time. The fact, the island of Limasawa or the municipality of Limasawa, is the place to go if you're seeking for dried nokus as a paslubong for friends and relatives. As stated in the story of Ang Nukos (Story2, Paragraph2- S3, P2) that, “Atong tabangan si Tiyo Simo sa paghaw-as sa mga nukos,".... Gidayungan nilang duha ang balde nga puno sa nukos. Nalipay si Tiyo Simo sa tabang ni Lito ug Berto. Gihatagan ni Tiyo Simo og usa ka kabo nga nukos ang duha ka mga bata. Malipayong namauli sila Berto ug Lito sa ilang balay kay aduna na silay sud-an sa pamahaw. (Let's help Uncle Simo get rid of the squid," he said. They helped lift the bucket full of squid. Uncle Simo was happy with the help of Lito and Berto. Uncle Simo gave squid to the two children. Berto and Lito happily went home because they already had something to eat for breakfast.).

Farming is also a common theme in the myths and tales. A statement demonstrating that the people of Southern Leyte are farmers ......kay mungadto man kay magdaro si Juan..... (going for plowing) (Ang Kamatajon sa Nagpababoy-baboy nga sa Hermohena sa Kamot ni Nong Arsenio, S30, P6). The assertions from the folktales depict the way of life in Southern Leyte at the time. These statements describe their sources of income as hunting wild animals, fishing, and farming. According to these statements, Southern Leyteňos have always worked hard to provide for their families. Southern Leyte's people are noted for their hard work. The province of Southern Leyte is known for its copra, rice, root crops, and tuba production. It also demonstrated that people have always worked hard to provide for their families. In reality, the second paragraph of Story 1 says, "Kay makuha nimu ni, mahimu kang milyunaryo kay mahal kaaju ning mananapa." (Because this animal is so valuable, catching it could make you a millionaire.) According to this remark, Southern Leyteňos are committed to have a better life and are willing to risk their lives to help their family. The term "mahimu kang milyunaryo 
kung makuha" means you can be a millionaire if you work hard enough implies that you must work hard in order to enjoy a good life.

Leyteňos is positive and determined to conquer all obstacles, according to Bautista (2018). During the Yolanda disaster in 2013, the residents of Leyte managed to grin despite the typhoon's ravages, and these smiles are full of hope, giving a message that all will be alright. The researcher agrees with Bautista's (2018) comment because, based on what has been witnessed in the current pandemic condition (COVID 19), there are several techniques to make money. The inhabitants of Southern Leyte are hopeful that, like the current COVID-19 pandemic, all of life's negative trials would pass.

\subsection{Leisure Embodied in Folktales}

People in the province of Southern Leyte have time to relax, no matter how poor they are or how low their income is. When conducting the interview, one of the participants shared simple ra among kalingawan dinhi, kung daghan ganing kuhag isda ug nindot ang harvest sa tanom sama sa mais, humay ug kopras. Magtigom ming mga silingan mag-inumay ug tuba, mangatawa ug magsajaw-sajaw. Lingaw nami kaaju (Our leisure here is simple. If the harvest was good and we got a lot from fishing, we gathered to have a drink, laugh out loud and dance.) kung buwanon ang mga batan-un niadtu manggawas arun magtigmu-tigmu. Kinsay dili makatubag nila butangan ug uling ang nawung. Kinsay daghan uling buut pasabot wa sija kamao sa tigmu (When the moon is full, the youth will go out to play riddle. Anyone who can't answer will smear dirt on the face. Anyone with a lot of dirt means a lot of riddles that he didn't answer). Another participant added, ....kung buwanon ang mga batan-un niadtu manggawas arun magtigmu-tigmu. Kinsay dili makatubag nila butangan ug uling ang nawung. Kinsay daghan uling buut pasabot wa sija kamao sa tigmu (When the moon is full, the youth will go out to play riddle. Anyone who can't answer will smear dirt on the face. Anyone with a lot of dirt means a lot of riddles that he didn't answer).

They spend their free time drinking coconut wine and playing during full moons. It's a basic pastime, but it's a lot of fun. Usually this is done on weekends. Finlay, Ram, Maggs, and Caldwell (2012), explained that it is typical for people to unwind over the weekend, whatever work there is. This is a way to condition oneself into entering work on weekdays.

\subsection{Cultural Practices in Lifestyle and Leisure Embedded in the Folktales}

Based on the results of the analysis of the folktales and the interviews conducted with the participants, different cultures can see their lifestyle and leisure. Folktales forms are among the gems worth conserving in the people's rich cultural legacy. The specific culture deeply rooted in the ancestors is tracked through retrieval, translation, and analysis. Folktakes analysis aids in providing a detailed picture of how people lived in the past. Because of frequent exposure to media and the constant input of contemporary technologies, folk literature does not draw the attention of many students. We can see the distinctive cultural practice in the lifestyles and leisure of the people at the time, particularly in Southern Leyte, via this study. Please see table 1 for more information.

Southern Leyte, like other Philippine regions, has cultural practices in lifestyles and recreation. What is shown in table 1 demonstrates this. The cultural customs developed from folktales are listed in the table as examples. In Southern Leyte, superstition, religious belief, and unity have been recognized as lifestyle habits. According to the respondents' interviews, practically everyone's labor is guided by superstitions, one of which is planting. It's no secret that farmers are among the most superstitious people on the planet. Few farming procedures are based on superstition, from weather predicting to knowing when to plant. It is clearly stated in the table that when it comes to planting, it is widely understood that the spreading of seeds for all plants that grow above ground should take place when the moon is waxing (so anytime between the new moon and the full moon). This means that planting should take place in the moonlight, as this is said to produce the finest results. Farmer never plants any fruit-bearing plants or trees when they are hungry, according to one of the respondents, because 
the plant will not grow well. Coconut trees were planted on the full moon to ensure a large harvest. Many people, including professionals, believe in superstition. A fisherman also said that if you go to a wake for the dead, you should never go ashore to the sea since there would almost likely be no fish to catch. According to Sierra, Hyman, and Turri (2018) the aforementioned is one of the ancestral cultural behaviors followed by the majority.

\section{Table 1}

Cultural Practices in Lifestyle and Leisure Embedded in the Folktales

\begin{tabular}{|c|c|c|c|}
\hline Category & Cultural Practice & & Excerpts \\
\hline \multirow{6}{*}{ Lifestyle } & \multirow{4}{*}{ Superstition } & D3 & $\begin{array}{l}\text { aw sa una magtanum gani mi ug kamote itunung jud ug buwanun } \\
\text { (Plant sweet potatoes when the moon is full) }\end{array}$ \\
\hline & & \multirow{3}{*}{ D6 } & $\begin{array}{l}\text { mag abli gani ug tindahan itunong ug } 8 \text { o } 10 \text { ang petsa ug magbuuk jud } \\
\text { ug nangka kay ang nangka humot ug paborito ni kadaghanan sa mga } \\
\text { tawu. Sa ato pa, ang imung tindahan humot pud ni sa mga tawo }\end{array}$ \\
\hline & & & balik-balikan ug palit ang tindahan \\
\hline & & & $\begin{array}{l}\text { (When you open a new store, set it on the } 8 \text { th or } 10 \text { th and prepare } \\
\text { jackfruit because it is fragrant and people's favorite, so many people go } \\
\text { to the store to buy) }\end{array}$ \\
\hline & Religious beliefs & D7 & $\begin{array}{l}\text { na practice pud na binditahan ang tindahan inig abli para daghang } \\
\text { musakang grasya (It is also a practice in Southern Leyte to bless the } \\
\text { newly opened store first so that many blessings will come) }\end{array}$ \\
\hline & Bayanihan system & D11 & naa man mi dinhi gitawag nga bolhon (We have a bolhon here) \\
\hline \multirow[t]{2}{*}{ Leisure } & \multirow{2}{*}{$\begin{array}{l}\text { Bonding with } \\
\text { neighbors }\end{array}$} & D5 & $\begin{array}{l}\text { simple ra among kalingawan dinhi, kung daghan ganing kuhag isda ug } \\
\text { nindot pagharvest sa tanom sama sa mais, humay ug kopras. Magtigom } \\
\text { ming mga silingan mag-inumay ug tuba, mangatawa ug } \\
\text { magsajaw-sajaw. Lingaw nami kaaju (Our leisure here is simple. If the } \\
\text { harvest was good and we got a lot from fishing, we gathered to have a } \\
\text { drink, laugh out loud and dance.) }\end{array}$ \\
\hline & & D8 & $\begin{array}{l}\text { kung buwanon ang mga batan-un niadtu manggawas arun } \\
\text { magtigmu-tigmu. Kinsay dili makatubag nila butangan ug uling ang } \\
\text { nawung. Kinsay daghan uling buut pasabot wa sija kamao sa tigmu } \\
\text { (When the moon is full, the youth will go out to play riddle. Anyone who } \\
\text { can't answer will smear dirt on the face. Anyone with a lot of dirt means } \\
\text { a lot of riddles that he didn't answer) }\end{array}$ \\
\hline & & & D-Dialogue \\
\hline
\end{tabular}

The origins of most superstitions can be found in history, mythology, culture, and folklore. As a result, they are never universal, and what is auspicious in one country may be a sign of ill fortune in another. When a businessman opens a new business, such as a store, the starting date should be 8 and 0 to maintain the business prosperous because 8 and 0 end up with an upstroke when written. Southern Leyteňos also believed that jackfruit's are lucky fruits. Jackfruit is fragrant and delicious, which is one of man's favorites. This means the newly opened store will also be a favorite of customers. According to Chinchanachokchai, Pusaksrikit, and Pongsakornrungsilp, (2016) superstitions are a common phenomenon in human society, especially in Asian cultures. Superstitious beliefs are one of the cultural practices of Asians that can harm people's social well-being, but many still believe in it, especially business people. This statement is confirmed in the result of this study. Respondents shared many beliefs that Southern Leyte followed when opening a new business. It merely revealed that cultural practices in people's lifestyles were difficult to eradicate at the time, as these views were still adopted by other businessmen today.

The bayanihan system is one good culture depicted in folktales. The bayanihan spirit in Southern Leyte is communal solidarity, which entails helping others without expecting anything in return in order to attain a specific purpose. Neighbors were expected to work together for those who had planned the planting and harvesting in advance. They call it bolhon and ajunay. The inhabitants of Southern Leyte highlight that the bolhon and ajunay cultural practices are a one-of-a-kind tradition. Southern Leyteňos survive their life as a result of this practice, which represents a collective activity in the past. It is evident why Southern Leyte can be regarded a thriving province since the people are unified, as can be seen in the table 1 .

Their leisure cultural activity appears to be straightforward. One of the respondents shared that one of their 
proudest customs is gathering, drinking tuba, and having fun storytelling and dancing whenever the harvest they planted is abundant, and many get from fishing. Respondents also stated that a considerable amount of money was not required to bond. One gallon of tuba is sufficient. The only thing that matters is that we unwind. When we're inebriated, our talent shines out because someone is singing, expressing their feelings through balak, and telling various arrogant stories. These activities have previously made us happy. These activities have previously made us happier and improved our neighborly solidarity. Young people could also easily congregate back then, especially when the moon was full. Because the youth will go out to play riddle when there is a full moon. It was the way they used to play back then. Those who are unable to respond will smear dirt over their faces. The mothers then would prepare dirt to use in their game as punishment. Anyone with a lot of dirt means a lot of riddles that he didn't answer.

The preceding explanations outline the cultural practice of Southern Leyte's lifestyle and leisure. Because some of these cultural customs are no longer done, the youth are unaware of them. This study's findings are quite valuable in familiarizing children with ancestry cultural customs. The researcher hopes and believes that the study's findings will help young people in Southern Leyte know that there are cultural customs in other provinces of the Philippines that they may be proud of.

\section{Conclusion and Recommendation}

Southern Leyteňos lifestyle includes hunting, pagtutuba, fishing, and farming, according to the results of a folklore-based analysis of lifestyles and leisure. Southern Leyteňos spend their spare time sharing stories, balak, dancing, singing, and drinking tuba. Because they were used to playing, young people found riddles to be quite useful. Southern Leyte is also a wellspring of cultural practices that they incorporate into their daily lives. Planting, fishing, and entrepreneurship are all superstitious notions. The bolhon or ajunay (bayanihan system) is regarded as a valuable cultural practice in which it serves as a tool for avoiding difficulties in jobs.

As a result, folklore reflects the people's lifestyles, leisure activities, and cultural customs, which they learned from their parents and elders. It simply goes to show that, like any other area, Southern Leyte is rich in cultural traditions and values that give the province its uniqueness. The findings of this study should be utilized and incorporated into teaching children about the culture of the people who live in the area where their school is located. The development of this study is in response to the adoption of the $\mathrm{K}-12$ curricula.

\section{References}

Abad, P., Tan, M., Baluyot, M., et al. (2014). Cultural beliefs on disease causation in the Philippines: Challenge and implications in genetic counseling. Journal Community Genetics, 5(4), 399-407.

Appell, G. (2010). Sabah oral literature project. World Oral literature project university.

Chinchanachokchai, S., Pusaksrikit, T., \& Pongsakornrungsilp, S. (2016). Exploring different types of superstitious beliefs in risk-taking behaviors: What we can learn from Thai consumers. Social Marketing Quarterly, 23(1), 47-63. https://doi.org/10.1177/1524500416672439

Dundes, A. (2007). Folklore as a Mirror of Culture. Meaning of Folklore. University Press of Colorado, Utah State University Press.

Finlay, A. K., Ram, N., Maggs, J. L., \& Caldwell, L. L. (2012). Leisure activities, the social weekend, and alcohol use: Evidence from a daily study of first-year college students. Journal of Studies on Alcohol and Drugs, 73(2), 250-259. https://doi.org/10.15288/jsad.2012.73.250

Guerero, S. (2019). A review of welfare issues in the coconut industry. https://dirp4.pids.gov.ph/ris/wp/alw07357.pdf

Nhung, P. (2016). Folktales as a valuable rich cultural and linguistic resource to teach a foreign language to young learners. International Journal of Education, Culture and Society, 1(1), 23-28.

Rahim, N., Pawi, A., \& Affendi, N. (2018). Integration of values and culture in Malay folklore animation. Pertanika Journal of Social Science and humanities, 26(1), 359-374. 
Borong, N. L.

Sierra, J., Hyman, M., \& Turri, A. (2018). Determinants and outcomes of superstitious beliefs: A multi-study approach. Journal of Marketing Management, 34(15-16), 1397-1417. https://doi.org/10.1080/0267257X.2018.1544923

Stavrou, E. (2015). Determining the cultural identity of a child through folk literature. American Journal of Educational Research, 3(4), 527-534. https://doi.org10.12691/education-3-4-20

Weisberger, M. (2017). Hunting big Game: Why people kill animals for fun. https://www.scientificamerican.com/article/hunting-big-game-why-people-kill-animals-for-fun/ 